\title{
Intelligence and social competence in university adaptation
}

\author{
Inteligência e competência social na \\ adaptação à universidade
}

\author{
Adriana Benevides SOARES \\ Vanuza FRANCISCHETTO' \\ Adriana Penha da Costa Lima PEÇANHA' \\ Jacqueline Maia de MIRANDA' \\ Betânia Marques da Silva DUTRA'
}

\begin{abstract}
This research paper concerns the influence of intelligence and social skills on the academic adjustment to university. Social demographic data was compiled based on gender, age, social class, and the type of teaching institution. A total of 393 university students took part in this survey, including 167 students under 20 years of age, 101 between 20 and 30, 31 between 31 and 40, and 26 over 40 years of age. Males accounted for 128 of the students, with 55 belonging to social class A, 134 to B, and 94 to classes C and D, and 184 participants attending public institutions. Data collection was performed using the Inventário de Habilidades Sociais, a Questionário de Vivências Acadêmicas (reduced version), and the Raven's test Matrizes Progressivas. The main results achieved presented significant correlations between social skills and academic adjustment, however, no significant results were found between intelligence and academic adaptation.
\end{abstract}

Uniterms: Academic adaptation; Intelligence; Social skills.

\section{Resumo}

O objetivo deste trabalho é verificar a influência da inteligência e das habilidades sociais na adaptação acadêmica à universidade, assim como de dados sociodemográficos tais como sexo, idade, classe social e tipo de instituição de ensino. Participaram deste estudo 393 estudantes universitários, sendo 128 homens; 167 sujeitos estavam na faixa etária de mais de 20 anos, 101 de 20 a 30 anos; 31 de 31 a 40 anos e 26 acima de 40 anos; 55 participantes da classe social A, 134 da B e 94 das classes C e D; 184 pertenciam a instituições públicas. Foram utilizados como instrumentos o Inventário de Habilidades Sociais, o Questionário de Vivências Acadêmicas (versão reduzida) e o teste Matrizes Progressivas de Raven. Foram obtidos como principais resultados correlações significativas entre Habilidades Sociais e Adaptação Acadêmica, mas não foram encontrados resultados significativos entre inteligência e adaptação acadêmica.

Unitermos: Adaptação acadêmica; Inteligência; Habilidades sociais.

\section{$\checkmark \mathbf{v} \mathbf{v}$}

1 Universidade Salgado de Oliveira, Programa de Pós-Graduação em Psicologia. R. Mal. Deodoro, 263, Centro, 24030-060, Rio de Janeiro, RJ, Brasil. Correspondência para/Correspondence to: A. B. SOARES. E-mail: <adribenevides@gmail.com>. 
New concepts of professionals to which the adjective "competent" can be applied seem to appear in contemporary society: the one that has the combination of technical and cognitive skills, and adds to that a list of interpersonal skills (Rubio \& Anzano, 1998). Social abilities are more and more demanded from people, which can make many technically skilled people in their fields have poor social interactional performances (Caballo, 2008).

It is frequently identified, in the field of Human Sciences, the importance of preservation and development of social interactions as a necessary element to personal growth and improvement in life quality (A. Del Prette \& Z.A.P. Del Prette, 1999). According to Caballo (1996), competent behaviors are a series of behaviors expressed by a person who promotes appropriate interaction to each situation. Universities are environments where interpersonal relations are established intensely. Studies performed by Almeida, Soares and Ferreira (1999), point out that the first university year is a moment of adjustments in which the adaptation of a freshman is tested every day.

Cognitive and adaptive skills are also important requirements for the good academic development at a university. Intelligence, which is very valued in intellectual environments, has incited the curiosity of many researchers. In a literature review, authors agree that few concepts have received so many definitions (Almeida, 1988; Sternberg, 2000). For many years the idea of intelligence was related to the development of academic skills (Machado, 1999), and nowadays intelligence is seen like a more comprehensive way, encompassing abilities of emotional, social and practical content.

In 1942, Cattel identified the existence of two intelligence factors which were later designated as fluid and crystalized intelligence factors, where the first was connected to nonverbal elements and developed little dependence upon previous knowledge and cultural aspects; the second represented competences for the solution of problems present in daily life, included in most of the required school activities (Schelini, 2006).

The uneasiness regarding the transition of high school students towards university life is relevant under this point of view, mainly if they are still in the first year the reception of the students and the adaptation process (Almeida et al., 1999; Almeida et al., 2002; A. Del Prette \& Z.A.P. Del Prette, 2005; Pires, Almeida \& Ferreira, 2000).

The main issues raised in this process are permeated by the interrelated and social barriers and obstacles of academic activities, related to the youngsters' vocational growth (Almeida, 1998; Cochrane, 1991; Pires et al., 2000) and also to cognitive skills and methods of knowledge systematizing. Researches in this field point out that most beginner students in universities meet academic and personal difficulties (Bariani \& Pavani, 2008; Carrara \& Betetto, 2009; Soares, Mello \& Baldez, 2011; Teixeira, Dias, Wottrich \& Oliveira, 2008) and sometimes economic (Lima \& Oliveira, 2010) and that there may be even an increase of mental illnesses that would lead to abandoning the course still in first year (Almeida et al., 1999; Almeida, Soares \& Ferreira, 2003; Santos, 2000).

Studies about intelligence and social skills (Carneiro, Dias, Nyaradi \& Aquino, 2000; Cunha, 2004) have not found correlations between these two concepts, showing that the fact that a student is academically intelligent does not grant them with the development of relational skills. Thus, the aim of this work is to investigate the influence of fluid intelligence and social skills at adapting to university, as well as to compare these three concepts to demographic variables such as gender, social class, age and type of educational institution.

\section{Method}

\section{Participants}

A total of 393 students participated in this research, 196 female, 128 male and 69 people did not answer. A total of 167 people were aged up to 20 years old, 101 between 20 and 30 years old, 31 between 31 and 40 years old and 26 above 40 years old - 68 people did not answer. As for marital status, 254 people were single, 59 people were married, 9 people were divorced and 71 persons did not answer. As for social class, 55 people were class A, 134 people were class B, 94 persons were class $C$ and D, and 110 people did not answer. 
Students were from different institutions: 184 students came from public institutions, 122 students were from private schools, and 87 students did not answer. The institutions were chosen according to a convenience criterion. Out of the 393 participants came from the arts and social areas, 26 from the biomedical sciences area, 117 students came from the sciences area and 70 people did not answer.

\section{Instruments}

Three instruments have been used: The Inventário de Habilidades Sociais (IHS) (A. Del Prette \& Z.A.P. Del Prette, 2001a), the Questionário de Vivências Acadêmicas (QVA-r), (Almeida et al., 2003), which were validated for the Brazilian university population by Gramado, Santos, Almeida, Soares and Guisande (2005) and Raven's test Matrizes Progressivas (1979). Socio demographic data such as age, sex, kind of higher education institution, social class and area of the course was collected.

1) The Inventário de Habilidades Sociais: The Inventário de Habilidades Sociais is a self-report instrument. It is composed by thirty eight items that describe social situations within different contexts. In the instructions for completing the $\mathrm{HS}$ the respondent is asked to estimate the frequency they react to each form suggested in the different items. The scale used is the Likert kind, with 5 points. Part of the items is written with negative connotation. The five factors that were assessed in the inventory are described this way: 1. It is called Assertiveness, which groups 11 items and reflects the assertiveness concept $(\alpha=0.96)$; 2 . It is called Affective Approach. It is formed by 7 items $(\alpha=0.86) ; 3$. It is called conversation and social resourcefulness. It is formed by 7 items $(\alpha=0.81)$; 4 . It is called self-exposition to unknown people or to new situations, formed by 4 items $(\alpha=0.75)$ and 5 . It is called self-control of aggressiveness to adverse situations with 3 items $(\alpha=0.74)$.

A Cronbach's alpha coefficient of 0.75 was found in the IHS internal consistency.

2) The Questionário de Vivências Acadêmicas: The Questionário de Vivências Acadêmicas - reduced, (QVA-r) is a self-report tool and aims at verifying behaviors of college students. The QVA-r consists of 55 items, five in the Likert format that has alternatives which range from 1 (nothing to do with me) to 5 (all to do with me) according to the degree of integration noticed by the student, totaling 275 possible points. The items are divided into five dimensions; Personal $(\alpha=0.87)$, Interpersonal $(\alpha=0.86)$, Vocational $(\alpha=0.91)$, Study and Learning ( $\alpha=0.82$ ) and Institutional ( $\alpha=0.71)$. 17 items, out of 55, have negative connotation.

3) The Matrizes Progressivas: Aiming at assessing the general intellectual capacity - factor $g$, the Matrizes Progressivas series A, B, C, D and E was used. It consists of items that involve, basically, comparisons of reasoning forms through analogy, with no relation to acquired knowledge. It consists of 60 items divided into five series of 12 items each. Each item has a matrix formed by abstract geometrical forms with a gap to be filled. Under the matrix there are 6 to 8 forms, and only one of those completes the matrix correctly.

The reliability of Matrizes Progressivas ranges through the retest-test method, between 0.83 and 0.93 , according to the age. The correlation with the Terman Merril scale is 0.86. A saturation factor of 0.82 in factor $g$ was identified.

\section{Procedures}

Three tools, from the socio demographic survey data questionnaire - individual way - were applied. There was no deadline to answer any of the three tools. All participants signed an informed consent. The study was approved by the Ethics Committee of the Universidade Salgado de Oliveira, protocol no 129/2009, on 02/25/2010 and all participants signed a Free Informed Consent prior to their inclusion in the sample.

\section{Results and Discussion}

As we can check in Table 1, all the IHS factors are correlated with each other, with IHS total and QVA-r total. None of the IHS factors correlate with the test Matrizes Progressivas, except for factor 2 (Affective Approach) ( $r=0.154 ; p<0,003)$. All QVA-r dimensions correlate with each other, with IHS total and QVS-r total. An exception may be noticed, the Study dimension does not correlate with the Institutional dimension. No 
correlation of the QVA-r dimensions with the test Matrizes Progressivas was found, except for the Personal dimension ( $r=0.146 ; p<0.004)$. Matrizes Progressivas does not correlate with any factor, except for factor 2 (Affective Approach) $(r=0.154 ; p<0.006)$. It does not correlate with any QVA-r dimension either, except for the Personal dimension ( $r=0.146 ; p<0.004)$.

The Inventário de Habilidades Sociais total and the QVA-r total also correlate with all IHS factors and with all QVA-r dimensions, however, they do not correlate with the test Matrizes Progressivas. The results for this study indicate correlations between academic adaptation and social skills, but show that social skills and academic adaptation do not correlate with intelligence.

Other studies point out similar results. Soares, Poubel and Mello (2009) came up with a comparative study in public and private teaching institutions and indicated that in public universities the fact that a student has a good social skills repertoire lead, mainly, to personal and contextual dimensions, while for private institution students, a good social skills repertoire correlated with the realization dimension. It was found that students from public institutions were more independent, academically speaking, and supported themselves through a social network of family and

Table 1

Correlation between the many social skills, intelligence and academic adaptation. Rio de Janeiro (RJ), 2010-2011

\begin{tabular}{|c|c|c|c|c|c|c|c|c|c|c|c|c|c|c|c|}
\hline & Variables & & 1 & 2 & 3 & 4 & 5 & 6 & 7 & 8 & 9 & 10 & 11 & 12 & 13 \\
\hline & Assertiveness & $r$ & 1 & 0.447 & 0.235 & 0.432 & 0.209 & 0.204 & 0.344 & 0.168 & 0.107 & 0.287 & 0.070 & 0.816 & 0.33 \\
\hline & (1) & $p$ & & 0.000 & 0.000 & 0.000 & 0.000 & 0.000 & 0.000 & 0.001 & 0.039 & 0.000 & 0.176 & 0.000 & 0.000 \\
\hline & Affective & $r$ & 0.447 & 1 & 0.263 & 0.319 & 0.347 & 0.302 & 0.312 & 0.297 & 0.154 & 0.374 & 0.154 & 0.71 & 0.425 \\
\hline & approach (2) & $p$ & 0.000 & & 0.000 & 0.000 & 0.000 & 0.000 & 0.000 & 0.000 & 0.003 & 0.000 & 0.003 & 0.000 & 0.000 \\
\hline & Conversation & $r$ & 0.235 & 0.263 & 1 & 0.366 & 0.314 & 0.326 & 0.178 & 0.108 & 0.155 & 0.206 & -0.098 & 00.62 & 0.287 \\
\hline & (3) & $p$ & 0.000 & 0.000 & & 0.000 & 0.000 & 0.000 & 0.001 & 0.038 & 0.003 & 0.000 & 0.058 & 0.000 & 0.000 \\
\hline & Exposure to & $r$ & 0.432 & 0.319 & 0.366 & 1 & 0.205 & 0.221 & 0.180 & 0.118 & 0.115 & 0.178 & 0.006 & 0.655 & 0.24 \\
\hline & unknown (4) & $p$ & 0.000 & 0.000 & 0.000 & & 0.000 & 0.000 & 0.000 & 0.023 & 0.026 & 0.001 & 0.912 & 0.000 & 0.000 \\
\hline & Self control & $r$ & 0.209 & 0.347 & 0.314 & 0.205 & 1 & 0275 & 0.325 & 0.254 & 0.156 & 0.171 & -0.021 & 0.486 & 0.345 \\
\hline & (5) & $p$ & 0.000 & 0.000 & 0.000 & 0.000 & & 0.000 & 0.000 & 0.000 & 0.002 & 0.001 & 0.676 & 0.000 & 0.000 \\
\hline & QVA Personal & $r$ & 0.204 & 0.302 & 0.326 & 0.221 & 0.275 & 1 & 0.275 & 0.371 & 0.221 & 0.345 & 0.146 & 0.369 & 0.649 \\
\hline & (6) & $p$ & 0.000 & 0.000 & 0.000 & 0.000 & 0.000 & & 0.000 & 0.000 & 0.000 & 0.000 & 0.004 & 0.000 & 0.000 \\
\hline & QVA & $r$ & 0.344 & 0.312 & 0.178 & 0.180 & 0.325 & 0.275 & 1 & 0.311 & 0.307 & 0.299 & 0.026 & 0.407 & 0.646 \\
\hline & Interpersonal (7) & $p$ & 0.000 & 0.000 & 0.001 & 0.000 & 0.000 & 0.000 & & 0.000 & 0.000 & 0.000 & 0.613 & 0.000 & 0.000 \\
\hline & QVA Career & $r$ & 0.168 & 0.297 & 0.108 & 0.118 & 0.254 & 0.371 & 0.311 & 1 & 0.470 & 0.417 & 0.058 & 0.252 & 0.745 \\
\hline & (8) & $p$ & 0.001 & 0.000 & 0.038 & 0.023 & 0.000 & 0.000 & 0.000 & & 0.000 & 0.000 & 0.250 & 0.000 & 0.000 \\
\hline & QVA & $r$ & 0.107 & 0.154 & 0.155 & 0.115 & 0.156 & 0.221 & 0.307 & 0.470 & 1 & 0.300 & 0.081 & 0.199 & 0.663 \\
\hline & Institutional (9) & $p$ & 0.039 & 0.003 & 0.003 & 0.026 & 0.002 & 0.000 & 0.000 & 0.000 & & 0.000 & 0.112 & 0.000 & 0.000 \\
\hline & QVA Study & $r$ & 0.287 & 0.374 & 0.206 & 0.178 & 0.171 & 0.345 & 0.299 & 0.417 & 0.300 & 1 & -0.056 & 0.386 & 0.707 \\
\hline & (10) & $p$ & 0.000 & 0.000 & 0.000 & 0.001 & 0.001 & 0.000 & 0.000 & 0.000 & 0.000 & & 0.266 & 0.000 & 0.000 \\
\hline \multirow{6}{*}{ 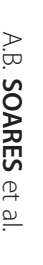 } & Intelligence & $r$ & 0.070 & 0.154 & -0.098 & 0.006 & -0.021 & 0.146 & 0.026 & 0.058 & 0.081 & -0.056 & 1 & 0.037 & 0.071 \\
\hline & (11) & $p$ & 0.176 & 0.003 & 0.058 & 0.912 & 0.676 & 0.004 & 0.613 & 0.250 & 0.112 & 0.266 & & 0.489 & 0.160 \\
\hline & IHS-Total & $r$ & 0.816 & 0.710 & 0.620 & 0.655 & 0.486 & 0.369 & 0.407 & 0.252 & 0.199 & 0.386 & 0.037 & 1 & 0.477 \\
\hline & $(12)$ & $p$ & 0.000 & 0.000 & 0.000 & 0.000 & 0.000 & 0.000 & 0.000 & 0.000 & 0.000 & 0.000 & 0.489 & & 0.000 \\
\hline & QVA-r-Total & $r$ & 0.330 & 0.425 & 0.287 & 0.240 & 0.345 & 0.649 & 0.646 & 0.745 & 0.663 & 0.707 & 0.071 & 0.477 & 1 \\
\hline & (13) & $p$ & 0.000 & 0.000 & 0.000 & 0.000 & 0.000 & 0.000 & 0.000 & 0.000 & 0.000 & 0.000 & 0.160 & 0.000 & \\
\hline
\end{tabular}

Note: Significant correlations marked in bold,

320

QVA-r: Questionário de Vivências Acadêmicas (Academic Experiences Questionnaire); IHS: Inventário de Habilidades Sociais (Social Skills Inventory). 
institutional members, whereas the students from private universities felt directed towards what they had decided to study, involved with the course and their teachers.

The fact that there was no correlation between the Study dimension and the Institutional dimension indicates that time management, daily planning of activities, punctuality, organization and efficiency at preparing tests do not depend upon the institution a student attends. Teixeira, Castro and Piccolo (2007) also investigated adaptation to university within students' universe and verified that the fact that a student is happy with their course and career has to do with the global judgment that the institution they attend to carries.

As for the test Matrizes Progressivas and IHS total, there was no correlation. The cognitive reasoning skills do not seem to depend on the relationship among people's behavioral skills. The research done by Carneiro et al. (2000) finds similar results, and also highlights a lack of correlation between the two concepts.

It was also noticed that the total intelligence score correlates with the QVA-r Personal dimension. What one can conclude from this relationship is that the students who have good logical - deductive capacity also tend to feel optimistic, with good self-esteem, for they can reach their own goals, and are more motivated to study, which facilitates their performance. Still in the same edition and focusing on analyzing how much are academic experiences of college students related to academic performance,

Cunha and Carrilho (2005) drew a research and concluded that performance in tests and assessments may be influenced by personal attributes and academic experiences lived by students in their first year in college. According to the presented results, fluid intelligence is not a significant factor in academic adaptation and does not relate to social skills. Nevertheless, social skills may facilitate academic success and minimize the difficulty factors in this adaptation.

The obtained results highlight that males had significantly higher scores than females in factor 1 (Assertiveness) ( $t=2.409 ; p=0.017)$, but in factor 2 (Affective Approach) ( $t=-2.105 ; p=0.036)$, females had significantly higher scores than males. Men showed higher scores in the test Matrizes Progressivas total $(t=2.905 ; p=0.004)$ while in QVA-r-Interpersonaldimension ( $t=-2.137 ; p=0.033$ ) and in QVA-r - Studydimension ( $t=-2.011 ; p=0.045)$ women had significantly higher scores than men (Table 2).

The results connected to social skills face historical and cultural characteristics that are socially perpetuated as time goes by: men have the role of mainstay of the family; they shall provide and decide about the behavior of family members, who in turn, must be subordinated to them. They are therefore appreciated for their assertiveness and even aggressiveness. Women have their behavior reinforced if they are affectionate and have submissive behavior, being then affectionate mediators of the family. Caballo (2008) states that the female gender is more competent at expressing positive feelings, and is, therefore, valued for that, while the male gender is often considered more aggressive and independent which is reinforced through the emission of these behaviors.

In a study performed by Lao et al. (Caballo, 2008) it was concluded that males were seen as more intelligent than females, however, both presented similar abilities. Higher scores of masculine assertiveness led to the idea that the feminine genre is less intelligent than the masculine. Caballo (2008) also states that there is no consensus in literature regarding the influence of the female and male behaviors within social situations.

Researches that measure intelligence between men and women have been an issue of the nowadays psychology (Silva, 2003). Still according to Silva (2003), studies have shown in their results slight inconsistencies regarding intelligence scores related to genre; sometimes favoring women, sometimes favoring men, even if with little difference; that is because there are, in specific tasks, differences in men and women's performances. The results of these studies related to fluid intelligence show that men present intellectual characteristics different from women's, more accuracy in problems that involve spatial representation and logical deductive reasoning, while women have a better performance in activities that demand production and language comprehension.

Through comparative results found in Table 3, there are significant differences among social classes 
Table 2

Comparisons of the three concepts by genre. Rio de Janeiro (RJ), 2010-2011

\begin{tabular}{|c|c|c|c|c|c|c|}
\hline Variables & Gender & $\mathrm{n}$ & M & SD & $t$ & $p$ \\
\hline \multirow[t]{2}{*}{ Assertiveness (1) } & Male & 123 & 10.01 & 3.043 & 2.40 & 0.017 \\
\hline & Female & 190 & 9.17 & 2.962 & & \\
\hline \multirow[t]{2}{*}{ Affective approach (2) } & Male & 127 & 8.44 & 1.93 & -2.10 & 0.036 \\
\hline & Female & 191 & 8.91 & 1.94 & & \\
\hline \multirow[t]{2}{*}{ Conversation (3) } & Male & 122 & 6.91 & 1.93 & -0.178 & 0.859 \\
\hline & Female & 189 & 6.95 & 2.01 & & \\
\hline \multirow[t]{2}{*}{ Exposure to unknown (4) } & Male & 126 & 3.28 & 1.15 & 0.398 & 0.691 \\
\hline & Female & 190 & 3.23 & 1.29 & & \\
\hline \multirow[t]{2}{*}{ Self control (5) } & Male & 126 & 2.87 & 0.78 & 0.829 & 0.408 \\
\hline & Female & 196 & 2.79 & 0.81 & & \\
\hline \multirow[t]{2}{*}{ QVA Personal (6) } & Male & 126 & 3.42 & 0.73 & -0.288 & 0.773 \\
\hline & Female & 196 & 3.45 & 0.68 & & \\
\hline \multirow[t]{2}{*}{ QVA Interpersonal (7) } & Male & 126 & 3.71 & 0.72 & -2.13 & 0.033 \\
\hline & Female & 196 & 3.88 & 0.69 & & \\
\hline \multirow[t]{2}{*}{ QVA Career (8) } & Male & 126 & 4.09 & 0.66 & -1.09 & 0.272 \\
\hline & Female & 196 & 4.18 & 0.67 & & \\
\hline \multirow[t]{2}{*}{ QVA Institutional (9) } & Male & 126 & 3.90 & 0.68 & 1.333 & 0.183 \\
\hline & Female & 196 & 3.80 & 0.65 & & \\
\hline \multirow[t]{2}{*}{ QVA Study (10) } & Male & 126 & 3.35 & 0.75 & -2.01 & 0.045 \\
\hline & Female & 196 & 3.53 & 0.75 & & \\
\hline \multirow[t]{2}{*}{ Intelligence } & Male & 128 & 49.82 & 8.00 & 2.90 & 0.004 \\
\hline & Female & 196 & 46.97 & 9.03 & & \\
\hline \multirow[t]{2}{*}{ IHS-Total } & Male & 117 & 31.71 & 6.33 & 0.67 & 0.498 \\
\hline & Female & 180 & 31.21 & 5.99 & & \\
\hline \multirow[t]{2}{*}{ QVA-Total } & Male & 126 & 18.50 & 2.57 & -1.26 & 0.206 \\
\hline & Female & 196 & 18.85 & 2.35 & & \\
\hline
\end{tabular}

Note: M: Mean; SD: Standard Deviation.

QVA-r: Questionário de Vivências Acadêmicas (Academic Experiences Questionnaire); IHS: Inventário de Habilidades Sociais (Social Skills Inventory).

in QVA-r Interpersonal dimension ( $t=3.055 ; p=0.049)$ and the test Matrizes Progressivas ( $t=9.612 ; p<0.001$ ), in other words, students from more advantaged social classes tend to have a better performance at interpersonal relations and better scores in fluid intelligence. As for the QVA-r Interpersonal dimension, $\rightarrow$ class A presented significant higher scores than classes 乞 $\quad C$ and D $(p=0.030)$ and class B presented significant 勇 higher scores than C and D ( $p=0.041)$. As for the test D Matrizes Progressivas, class A presented significant higher scores than classes $C$ and $D(p<0.001)$ and class $B$ presented significant higher scores than classes $C$ and

$322 \mathrm{D}(p<0.001)$.
It is noticed that students from richer social classes present themselves as more integrated to academic life either through a better interpersonal relationship or by presenting a better reasoning ability to solve problems given to them. Regarding interpersonal relationships, students from social class A assume they have good friends and believe that having colleagues is important for personal growth; they try to have long lasting friendships and relate to their colleagues away from university life. Those interpersonal and social relationships of affection may favor adaptation to the university, strengthening the bond with the course and the institution. The established commitment and social support sustain the students and make them 
Table 3

Comparisons according to social class. Rio de Janeiro (RJ), 2010-2011

\begin{tabular}{|c|c|c|c|c|c|c|}
\hline Variables & Class & $n$ & M & SD & $\mathrm{F}$ & $p$ \\
\hline \multirow[t]{3}{*}{ Assertiveness (1) } & A & 55 & 10.05 & 3.11 & 1.495 & 0.226 \\
\hline & B & 131 & 9.43 & 3.15 & & \\
\hline & CeD & 86 & 9.12 & 3.14 & & \\
\hline \multirow[t]{3}{*}{ Affective approach (2) } & A & 55 & 9.01 & 1.91 & 0.992 & 0.372 \\
\hline & B & 133 & 8.59 & 2.03 & & \\
\hline & CeD & 91 & 8.59 & 1.96 & & \\
\hline \multirow[t]{3}{*}{ Conversation (3) } & A & 55 & 7.42 & 1.91 & 2.14 & 0.119 \\
\hline & B & 131 & 6.74 & 2.13 & & \\
\hline & CeD & 86 & 6.97 & 1.96 & & \\
\hline \multirow[t]{3}{*}{ Exposure to unknown (4) } & A & 55 & 3.32 & 1.27 & 0.43 & 0.649 \\
\hline & B & 131 & 3.15 & 1.29 & & \\
\hline & CeD & 89 & 3.25 & 1.09 & & \\
\hline \multirow[t]{3}{*}{ Self control (5) } & A & 55 & 3.01 & 0.71 & 0.95 & 0.388 \\
\hline & B & 133 & 2.84 & 0.84 & & \\
\hline & CeD & 93 & 2.84 & 0.85 & & \\
\hline \multirow[t]{3}{*}{ QVA Personal (6) } & A & 55 & 3.48 & 0.67 & 0.27 & 0.760 \\
\hline & B & 133 & 3.41 & 0.76 & & \\
\hline & CeD & 93 & 3.47 & 0.66 & & \\
\hline \multirow[t]{3}{*}{ QVA Interpersonal (7) } & A & 55 & 3.94 & 0.69 & 3.05 & 0.049 \\
\hline & B & 133 & 3.87 & 0.72 & & \\
\hline & CeD & 93 & 3.67 & 0.73 & & \\
\hline \multirow[t]{3}{*}{ QVA Career (8) } & A & 55 & 4.05 & 0.65 & 0.55 & 0.572 \\
\hline & B & 133 & 4.14 & 0.65 & & \\
\hline & CeD & 93 & 4.17 & 0.69 & & \\
\hline \multirow[t]{3}{*}{ QVA Institutional (9) } & A & 55 & 3.82 & 0.65 & 0.85 & 0.425 \\
\hline & B & 133 & 3.90 & 0.66 & & \\
\hline & CeD & 93 & 3.78 & 0.72 & & \\
\hline \multirow[t]{3}{*}{ QVA Study (10) } & A & 55 & 3.36 & 0.86 & 0.94 & 0.391 \\
\hline & B & 133 & 3.48 & 0.73 & & \\
\hline & CeD & 93 & 3.54 & 0.81 & & \\
\hline \multirow[t]{3}{*}{ Intelligence } & A & 55 & 50.15 & 7.21 & 9.61 & 0.000 \\
\hline & B & 134 & 48.60 & 8.86 & & \\
\hline & CeD & 94 & 44.29 & 9.75 & & \\
\hline \multirow[t]{3}{*}{ IHS-Total } & A & 55 & 32.80 & 6.48 & 1.88 & 0.153 \\
\hline & B & 124 & 30.94 & 6.65 & & \\
\hline & CeD & 80 & 30.95 & 5.52 & & \\
\hline \multirow[t]{3}{*}{ QVA-Total } & A & 55 & 18.65 & 2.39 & 0.15 & 0.858 \\
\hline & B & 133 & 18.80 & 2.46 & & \\
\hline & CeD & 93 & 18.63 & 2.48 & & \\
\hline
\end{tabular}

Note: M: Mean; SD: Standard Deviation.

QVA-r: Questionário de Vivências Acadêmicas (Academic Experiences Questionnaire); IHS: Inventário de Habilidades Sociais (Social Skills Inventory).

neither demotivated nor dropouts (Almeida et al., 2002).

Some studies have shown the relationship between social class and institutional bond; Ribeiro (2005), for example, conducted a study with 155 students from a low socio economic and cultural level that did not adapt to the university context, aimed at high and middle classed people. Machado, Melo Filho and Pinto (2005) also point out one of the reasons for the difficulty to academic adaptation as the family financial situation, in other words, students coming from less favored social classes tend to have more difficulty

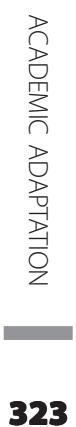

323 
throughout the university environment adaptation process than students from richer social classes.

As for the scores for fluid intelligence social class A scores higher comparing to the others. Some studies show that intelligence characteristics are related to social classes. Silva and Santos (2004) observe that students with higher income who attended high school in private schools and had significant access to reading had better academic performance throughout their respective college courses. Besides, in Soares, Emmerick and Vicente (2010) study, it was found that university students from high social class, from different institutions, and who formed the students' body in courses considered more difficult because more points are required to enter them, showed better performance at text comprehension than those who belonged in social classes of lower incomes.

Some significant differences were found within the many age groups in factor 3 (conversation and social easiness). People who are above 40 years old present significant higher scores than those who are up to 20, between 21 and 30 and between 31 and 40 years old. In factor 4 (self-exposition to unknown people or to new situations), people aged above 40 showed significant higher scores than those who are up to 20, between 21 and 30 years old. At the IHS Total people aged above 40 showed significant higher scores than those who are up to 20 and between 21 and 30 years old (Table 4).

At the Questionário de Vivências Acadêmicas Institutional dimension people aged up to 20 years old presented higher scores than those between 21 and 30 years old and those between 31 and 40 years old; students who were above 40 presented higher scores than those who were between 21 and 30, 31 and 40. At the QVA-r dimension Study people who were above 40 presented higher scores than those who were up to 20, between 21 and 30 years old. At the QVA-r Total people who were above 40 showed significant higher scores than those who were between 21 and 30 . At the test Matrizes Progressivas people who were up to 20 presented higher scores than those who were between 21 and 30, 31 and 40 and above 40 years old.

As for the results related to social skills it was observed that the older students above 40 , are more social skilled than the younger, mainly regarding social easiness and self-exposition to unknown people. They present themselves as more skilled at conversation and at establishing contact with strangers, which allows the inference that they are more aware of social rules (A. Del Prette \& Z.A.P. Del Prette, 2001 b).

Raposo and Gunter (2008), in a research with more than 45 university students, investigated the reasons why an adult goes to university. They identified as important reasons the search for new objectives, the necessity to meet needs of the work market, and personal fulfillment among others.

Among the described descriptors an important characteristic, loss in previous relationships such as marriage - separation and children that supported and gave meaning to those people's lives, appeared. Therefore, entering university was seen as a chance to establish new bonds and fruitful interpersonal relationships. As a consequence the high score in social easiness and self-exposition to strangers for those people can be seen as results from previous social and emotional experiences that enabled the building of important experiences for social coexistence.

There are two situations in academic adjustment: the one in which very young or older students - older than 40 - are the best adjusted to the institution they attend.

Noronha, Martins, Gurgel and Ambiel (2009) stated, in a survey with 159 students that the ones who were older than 26 scored higher grades - averages than the others in the Career dimension, which suggests that participants of that age tend to have academic experiences that are more adjustable towards vocation and involvement with the chosen course.

As for fluid intelligence, there were results indicating that the younger students are the ones who have more cognitive resources for performing reasoning intellectual activities. The cognitive flexibility of young people might have allowed them higher fluid intelligence scores and lower stiffness at the mental configuration determined by the experience of the older students.

The cognitive flexibility of the young may have allowed them into higher fluid intelligence scores and less stiffness in the determined mental configuration through the experience of older people. In this sense, Oliveira (2008), in a research held with 261 students, pointed out that older students showed better text comprehension compared with the younger ones. 
Table 4

Comparisons by age. Rio de Janeiro (RJ), 2010-2011

\begin{tabular}{|c|c|c|c|c|c|c|}
\hline Variables & Age & $n$ & M & SD & $\mathrm{F}$ & $p$ \\
\hline \multirow[t]{4}{*}{ Assertiveness (1) } & Up to 20 years old & 161 & 9.48 & 2.75 & 0.90 & 0.438 \\
\hline & 21 to30 years old & 98 & 9.21 & 2.77 & & \\
\hline & 31 to 40 years old & 28 & 10.13 & 4.56 & & \\
\hline & over 40 years old & 26 & 9.97 & 3.55 & & \\
\hline \multirow[t]{4}{*}{ Affective approach (2) } & Up to 20 years old & 166 & 8.64 & 1.85 & 2.35 & 0.072 \\
\hline & 21 to 30 years old & 98 & 8.57 & 2.14 & & \\
\hline & 31 to 40 years old & 31 & 9.00 & 1.76 & & \\
\hline & over 40 years old & 24 & 9.65 & 1.85 & & \\
\hline \multirow[t]{4}{*}{ Conversation (3) } & Up to 20 years old & 163 & 6.74 & 1.98 & 4.11 & 0.007 \\
\hline & 21 to 30 years old & 97 & 6.92 & 1.86 & & \\
\hline & 31 to 40 years old & 30 & 7.08 & 2.35 & & \\
\hline & over 40 years old & 22 & 8.29 & 1.46 & & \\
\hline \multirow[t]{4}{*}{ Exposure to unknown (4) } & Up to 20 years old & 162 & 3.15 & 1.16 & 3.45 & 0.017 \\
\hline & 21 to 30 years old & 98 & 3.20 & 1.31 & & \\
\hline & 31 to 40 years old & 31 & 3.41 & 1.42 & & \\
\hline & over 40 years old & 26 & 3.96 & 1.03 & & \\
\hline \multirow[t]{4}{*}{ Self control (5) } & Up to 20 years old & 166 & 2.80 & 0.77 & 1.62 & 0.183 \\
\hline & 21 to 30 years old & 100 & 2.76 & 0.85 & & \\
\hline & 31 to 40 years old & 31 & 3.03 & 0.77 & & \\
\hline & over 40 years old & 26 & 3.04 & 0.80 & & \\
\hline \multirow[t]{4}{*}{ QVA Personal (6) } & Up to 20 years old & 166 & 3.41 & 0.71 & 1.96 & 0.119 \\
\hline & 21 to 30 years old & 101 & 3.38 & 0.67 & & \\
\hline & 31 to 40 years old & 31 & 3.61 & 0.62 & & \\
\hline & over 40 years old & 25 & 3.69 & 0.81 & & \\
\hline \multirow[t]{4}{*}{ QVA Interpersonal (7) } & Up to 20 years old & 166 & 3.87 & 0.69 & 0.81 & 0.485 \\
\hline & 21 to 30 years old & 101 & 3.73 & 0.76 & & \\
\hline & 31 to 40 years old & 31 & 3.82 & 0.75 & & \\
\hline & over 40 years old & 25 & 3.82 & 0.56 & & \\
\hline \multirow[t]{4}{*}{ QVA Career (8) } & Up to 20 years old & 166 & 4.18 & 0.64 & 2.06 & 0.104 \\
\hline & 21 to 30 years old & 101 & 4.03 & 0.75 & & \\
\hline & 31 to 40 years old & 31 & 4.20 & 0.61 & & \\
\hline & over 40 years old & 25 & 4.37 & 0.62 & & \\
\hline \multirow[t]{4}{*}{ QVA Institutional (9) } & Up to 20 years old & 166 & 3.94 & 0.61 & 4.10 & 0.007 \\
\hline & 21 to 30 years old & 101 & 3.72 & 0.73 & & \\
\hline & 31 to 40 years old & 31 & 3.62 & 0.76 & & \\
\hline & over 40 years old & 25 & 4.02 & 0.39 & & \\
\hline \multirow[t]{4}{*}{ QVA Study (10) } & Up to 20 years old & 166 & 3.43 & 0.72 & 4.13 & 0.007 \\
\hline & 21 to 30 years old & 101 & 3.38 & 0.79 & & \\
\hline & 31 to 40 years old & 31 & 3.57 & 0.79 & & \\
\hline & over 40 years old & 25 & 3.94 & 0.79 & & \\
\hline \multirow[t]{4}{*}{ Intelligence } & Up to 20 years old & 167 & 50.13 & 7.73 & 7.08 & 0.000 \\
\hline & 21 to 30 years old & 101 & 46.36 & 9.35 & & \\
\hline & 31 to 40 years old & 31 & 44.74 & 10.39 & & \\
\hline & over 40 years old & 26 & 45.23 & 8.02 & & \\
\hline \multirow[t]{4}{*}{ IHS-Total } & Up to 20 years old & 155 & 30.99 & 5.47 & 3.86 & 0.010 \\
\hline & 21 to 30 years old & 93 & 30.85 & 6.18 & & \\
\hline & 31 to 40 years old & 27 & 32.57 & 8.42 & & \\
\hline & over 40 years old & 22 & 35.27 & 5.79 & & \\
\hline \multirow[t]{4}{*}{ QVA-Total } & Up to 20 years old & 166 & 18.82 & 2.27 & 3.20 & 0.024 \\
\hline & 21 to 30 years old & 101 & 18.24 & 2.65 & & \\
\hline & 31 to 40 years old & 31 & 18.83 & 2.45 & & \\
\hline & over 40 years old & 25 & 19.83 & 2.30 & & \\
\hline
\end{tabular}

Note: M: Mean; SD: Standard Deviation.

QVA-r: Questionário de Vivências Acadêmicas (Academic Experiences Questionnaire); IHS: Inventário de Habilidades Sociais (Social Skills Inventory). 
Therefore, it was concluded that world experience helped the older students to show their crystalized intellectual capacity.

According to Table 5 students from public institutions had significant lower scores than those from private institutions in factors 3 (conversation and social easiness) ( $t=-4.124 ; p=0.000), 5$ (self-control of aggressiveness in adverse situations) ( $t=-2.489 ; p=0.013)$, and as for the QVA-r Study dimension ( $t=-2899 ; p=0.004)$. The inverse situation happened regarding factors QVA-r Institutional dimension ( $t=5.547) ; p=0.000$ ) and for the test Matrizes Progressivas ( $t=7.049 ; p=0.000$ ) where students from public institutions scored significant higher scores than students from private institutions. In factor 3, which demands, mainly, social easiness, students from public institutions showed less social easiness than the ones from private institutions. In factor
5 (self-control of aggressiveness to adverse situations), which demands anger and aggressiveness control, it was found that students from public institutions have less self-control of aggressiveness in adverse situations than students from private institutions.

Soares, Naiff, Fonseca, Cardozo and Baldez (2009) carried a study in which it was possible to compare teachers' social skills in many different levels, and compare socio-demographic variables such as gender, kind of institution, schooling and field of action. The results of this study show that teachers from public and private institutions presented good portfolios of social skills and set good behavioral examples to their students.

In the QVA-r dimension Study - learning in which study habits, time management, use of learning tools in campus and preparation for tests are assessed,

Table 5

Comparisons by institution. Rio de Janeiro (RJ), 2010-2011

\begin{tabular}{|c|c|c|c|c|c|c|}
\hline Variables & Institution & $n$ & Average & SD & $t$ & $p$ \\
\hline \multirow[t]{2}{*}{ Assertiveness (1) } & Public & 179 & 9.6209 & 2.81715 & 0.83 & 0.405 \\
\hline & Private & 133 & 9.3355 & 3.21196 & & \\
\hline \multirow[t]{2}{*}{ Affective approach (2) } & Public & 182 & 8.5943 & 1.88521 & -1.41 & 0.158 \\
\hline & Private & 135 & 8.9068 & 2.02201 & & \\
\hline \multirow[t]{2}{*}{ Conversation (3) } & Public & 178 & 6.5806 & 2.04174 & -4.12 & 0.000 \\
\hline & Private & 132 & 7.4692 & 1.74292 & & \\
\hline \multirow[t]{2}{*}{ Exposure to unknown (4) } & Public & 180 & 3.2010 & 1.20852 & -0.91 & 0.363 \\
\hline & Private & 135 & 3.3297 & 1.28267 & & \\
\hline \multirow[t]{2}{*}{ Self control (5) } & Public & 183 & 2.7251 & 0.78934 & -2.48 & 0.013 \\
\hline & Private & 138 & 2.9475 & 0.79679 & & \\
\hline \multirow[t]{2}{*}{ QVA Personal (6) } & Public & 183 & 3.4515 & 0.71150 & -0.04 & 0.965 \\
\hline & Private & 138 & 3.4550 & 0.67923 & & \\
\hline \multirow[t]{2}{*}{ QVA Interpersonal (7) } & Public & 183 & 3.7882 & 0.71768 & -0.97 & 0.330 \\
\hline & Private & 138 & 3.8664 & 0.70091 & & \\
\hline \multirow[t]{2}{*}{ QVA Career (8) } & Public & 183 & 4.1658 & 0.69730 & 0.26 & 0.793 \\
\hline & Private & 138 & 4.1458 & 0.64904 & & \\
\hline \multirow[t]{2}{*}{ QVA Institutional (9) } & Public & 183 & 4.0276 & 0.56308 & 5.54 & 0.000 \\
\hline & Private & 138 & 3.6151 & 0.72398 & & \\
\hline \multirow[t]{2}{*}{ QVA Study (10) } & Public & 183 & 3.3692 & 0.71457 & -2.89 & 0.004 \\
\hline & Private & 138 & 3.6137 & 0.79029 & & \\
\hline \multirow[t]{2}{*}{ Intelligence } & Public & 185 & 50.9568 & 7.16788 & 7.04 & 0.000 \\
\hline & Private & 138 & 44.2391 & 9.32742 & & \\
\hline \multirow[t]{2}{*}{ IHS-total } & Public & 170 & 30.9026 & 6.00457 & -1.71 & 0.087 \\
\hline & Private & 126 & 32.1162 & 6.04165 & & \\
\hline \multirow[t]{2}{*}{ QVA Total } & Public & 183 & 18.8023 & 2.35432 & 0.38 & 0.700 \\
\hline & Private & 138 & 18.6959 & 2.56579 & & \\
\hline
\end{tabular}

Note: M: Mean; SD: Standard Deviation.

326 QVA-r: Questionário de Vivências Acadêmicas (Academic Experiences Questionnaire); IHS: Inventário de Habilidades Sociais (Social Skills Inventory). 
students from public institutions got lower scores than those from private institutions. On the other hand, students from public institutions scored higher marks than students from private institutions at the QVA-r Institutional dimension, where students'appreciation for the teaching institution attended, the wish to stay or change schools and the knowledge and appreciation of existing infrastructure is assessed. In the state of Roraima a study carried by Neves and Domingues (2006) showed that students from public institutions appreciate their institution more, due to the their better performance; nevertheless, those students are little interested in managing their time, developing study habits or in using learning tools. Students from private institutions, evaluated for their inferior performance to that in public institutions, show less appreciation for the teaching institution and are, at the same time, more dedicated than students from public institutions regarding time management, way of studying and use of learning tools.

In the test Matrizes Progressivas, students from public institutions were evaluated as more intelligent than those from private institutions. Once they realized they were more intelligent they seemed to value time issues and general skill less than students from private institutions.

\section{Final Consideration}

The results of this study indicate correlation between academic adaptation and social skills; however, they show that both social skills and academic adaptation do not correlate with intelligence. It also points out that regarding academic adaptation, intellectual reasoning skills seem to be independent from behavioral skills of interpersonal relationships.

Therefore, the importance of social skills for students' coexistence within the academic reality was evident, once the failure or success of these students does not represent a pedagogical nor cognitive issue, for results show that social level, age, genre and the kind of institution interfere with promotion, adaptation and maintenance of the young person in the university as well as changes that might occur within this context.

The results of this research contribute, mainly to studies regarding college dropouts, once students who are not adapted leave the course more easily. There must be especial care in the transition from high school to college, favoring adaptation to academic life. To help with this transition there might be necessary, in high school, the creation of professional orientation projects aiming at giving the student a global view of the market and its relations with academic life, as well as the development of public politics that favor such transition. In college, there is need for a welcoming practice for better adaptation of the freshman, taking them through physical space recognition, procedures and rules that may welcome the college student, besides promoting projects that stimulate the development of facilitating social competences of better interpersonal performances.

Besides investing in scientific knowledge, universities also form a context in which their social skills may be developed, thus it is necessary to rethink the efficiency of a student's entrance in college, in other words, the way colleges present their academic and social content to students so that the building of strategies for better adaptation to academic life is given. Students who enter college need to have their potential worked on as to form a set of skills that enable them to fully coexist in society.

\section{References}

Almeida, L. S. (1988). Teorias da inteligência. Porto: Jornal de Psicologia.

Almeida, L. S. (1998). Questionário de vivências acadêmicas para jovens universitários: estudo de construção e de validação. Revista Galego-Portuguesa de Psicologia e Educação, 2(3), 113-130.

Almeida, L. S., Soares, A. P. C., \& Ferreira, J. A. G. (1999). Adaptação, rendimento e desenvolvimento dos estudantes no ensino superior: construção, validação do questionário acadêmico de vivências acadêmicas-relatórios de investigação. Braga: Universidade de Minho.

Almeida, L. S., Soares, A. P. C., \& Ferreira, J. A. G. (2003). Questionário de vivências (QVA e QVA-r). In M. M. Golçalves, M. R. Simões, L. S. Almeida \& C. Machado (Eds.), Avaliação psicológica: instrumentos validados para a população portuguesa. Coimbra: Quarteto.

Almeida, L. S., Vasconcelos, R., Morais, N., Paulo, J. B., Rebouta, L., \& Passos, M. S. (2002). Favorecer o sucesso acadêmico no $1^{\circ}$ ano: uma experiência junto de alunos de engenharia de materiais da Universidade do Minho. Proceedings VII International Conference on Engineering and Technology Education, Intertech. Santos, Brasil.

Bariani, I. C. D., \& Pavani, R. (2008). Sala de aula na universidade: espaço de relações interpessoais e participação acadêmica. Estudos de Psicologia (Campinas), 25(1), 67-75. doi: 10.1590/S0103-166X2009000300007. 
Caballo, V. E. (1996). Manual de técnicas de terapia y modificacion de conducta. Madri: Siglo Veintiuno.

Caballo, V. E. (2008). Manual de avaliação e treinamento das habilidades sociais. São Paulo: Santos Editora.

Carneiro, E. G., Dias, R. O., Nyaradi, O., \& Aquino, S. (2000). Habilidades sociais e cognitivas em estudantes universitários brasileiros. V Congresso Galego-Portugues de Psicopedagoxía Actas, 4(6), 689-697.

Carrara, K., \& Betetto, M. F. (2009). Formação ética para a cidadania: uma investigação de habilidades sociais medidas pelo inventário de habilidades sociais. Estudos de Psicologia (Campinas), 26(3), 337-347. doi: 10.1590/S0 103-166×2009000300007.

Cochrane, C. (1991). First year at university: A study of mature female students. Irish Journal of Education, 25(1-2), 42-51.

Cunha, S. M. (2004). A inteligência e as habilidades sociais na adaptação de alunos ao curso superior: um estudo com alunos do $1^{\circ}$ ano do Instituto Militar de Engenharia (Dissertação de mestrado não-publicada). Universidade Gama Filho.

Cunha, S., \& Carrilho, D. (2005). O processo de adaptação ao ensino superior e o rendimento acadêmico. Psicologia Escolar e Educacional, 9(2), 215-224.

Del Prette, Z. A. P., \& Del Prette, A. (1999). Psicologia das habilidades sociais: terapia e educação. Petrópolis: Vozes.

Del Prette, A., \& Del Prette, Z. A. P. (2001a). Inventário de habilidades sociais: manual de aplicação, apuração e interpretação. São Paulo: Casa do Psicólogo.

Del Prette, A., \& Del Prette, Z. A. P. (2001b). Psicologia das relações interpessoais: vivências para o trabalho em grupo. Petrópolis: Vozes.

Del Prette, A., \& Del Prette, Z. A. P. (2005). Psicologia das habilidades sociais na infância: teoria e prática. Petrópolis: vozes.

Gramado, J. I. F., Santos, A. A. A., Almeida, L. S., Soares, A. P., \& Guisande, M. A. (2005). Integração acadêmica de estudantes universitários: contributos para adaptação e validação do QVA-r no Brasil. Psicologia e Educação, 12(2), 31-43.

Lima, J. B. G., \& Oliveira, R. D. (2010). Estudo da evasão escolar do ponto de vista econômico: o caso dos centros universitários Camilianos do Brasil. InterSciencePlace, 3(12), 168-193.

Machado, N. J. (1999). Epistemologia e didática: as concepções de conhecimento e inteligência e a prática docente. São Paulo: Cortez.

Machado, S. P., Melo Filho, J. M., \& Pinto, A. C. (2005). A evasão nos cursos de graduação de química: uma experiência de sucesso feita no Instituto de Química da Universidade Federal do Rio de Janeiro para diminuir a evasão. Química Nova, 28, S41-S43.

Neves, A. P., \& Domingues, M. J. (2006). Desempenho dos estudantes das instituições Publicas e privadas no ENADE: um estudo no estado de Roraima. Brasília: Inep. Recuperado em novembro 10, 2010, disponível em <http:// www.aedb.br/seget/artigos>.

Noronha, A. P. P., Martins, D. F., Gurgel, M. G. A., \& Ambiel, R. A. M. (2009). Estudo correlacional entre interesses profissionais e vivências acadêmicas. Psicologia Escolar e Educacional, 13(1), 143-154.
Oliveira, K. L. (2008). Compreensão da leitura, atitudes de leitura e desesperança em universitários. Psicologia Ciência e Profissão, 28(4), 820-831.

Pires, H. S., Almeida, L., \& Ferreira, J. A. (2000). Questionário de Vivências Acadêmicas (QVA) aos estudantes universitários dos PALOP. In A. P. Soares, A. Osório, J. V. Capela, L. S. Almeida, R. M. Vasconcelos \& S. M. Caíres (Eds.), Transição para o ensino superior (pp.119-127). Braga: Universidade do Minho.

Raposo, M. S. P., \& Gunter, I. A. (2008). O ingresso na universidade após os 45 anos: um evento não-normativo. Psicologia em Estudo, 13(1), 123-131.

Raven, J. C. (1979). Matrizes progressivas: escala geral. Rio de Janeiro: CEPA.

Ribeiro, M. A. (2005). O projeto profissional familiar como determinante da evasão universitária: um estudo preliminar. Revista Brasileira de Orientação Profissional, 6(2), 55-70.

Rubio, J. M. L., \& Anzano, S. M. (1998). Aproximación conceptual a las habilidades sociales. In F. Gil, \& J. M. Léon. Habilidades sociales: teoría, investigación e intervención, (pp.13-23). Madrid: Síntesis.

Santos, L. T. M. (2000). Vivências acadêmicas e rendimento escolar: estudos com alunos universitários do $1^{\circ}$ ano. Braga: Universidade do Minho.

Schelini, P. W. (2006). Teoria das inteligências fluida e cristalizada: início e evolução. Estudos de Psicologia (Natal), 11(3), 323-332.

Silva, J. G. (2003). Inteligência humana abordagens biológicas e cognitivas. São Paulo: Lovise.

Silva, M. J. M., \& Santos, A. A. A. (2004). A avaliação da compreensão em leitura e o desempenho acadêmico de universitários. Psicologia em Estudo, 9(3), 459-457.

Soares, A. B., Emmerick, T. A., \& Vicente, A. L. (2010). Avaliação dos níveis de compreensão de textos em estudantes universitários. Estudos e Pesquisas em Psicologia, 10(3), 818-832.

Soares, A. B., Mello, T. V., \& Baldez, M. O. M. (2011). Vivências acadêmicas em estudantes universitários do Estado do Rio de Janeiro. Interação em Psicologia, 15(1), 59-69.

Soares, A. B., Naiff, L. A., Fonseca, L. B., Cardozo, A., \& Baldez, M. O. (2009). Estudo comparativo de habilidades sociais e variáveis sociodemográficas de professores. Psicologia Teoria e Prática, 11(1), 35-49.

Soares, A. B., Poubel, L. N., \& Mello, T. V. S. (2009). Habilidades sociais e adaptação acadêmica: um estudo comparativo em instituições de ensino público e privado. Aletheia, 29, 27-42.

Sternberg, R. J. (2000). Psicologia cognitiva. Porto Alegre: Artmed.

Teixeira, M. A. P., Castro, G. D., \& Piccolo, L. R. (2007). Adaptação à universidade em estudantes universitários: um estudo correlacional. Interação em Psicologia, 11 (2), 211-220.

Teixeira, M. A. P., Dias, A. C. G., Wottrich, S. H., \& Oliveira, A. M. (2008). Adaptação à universidade em jovens calouros. Psicologia Escolar e Educacional, 12(1), 158-202.

Received on: 16/11/2011

Final version on: 4/9/2012

Approved on: 24/9/2012 